\title{
EKSISTENSI BUDAYA KASEISE (TOLONG-MENOLONG) DALAM PENYELENGGARAAN PERNIKAHAN SUKU MUNA (Studi di Desa Kombikuno Kecamatan Napano Kusambi)
}

\author{
Oleh: Julaman K., Bahtiar, dan Sarpin
}

\begin{abstract}
Abstrak
Penelitian ini bertujuan untuk mengetahui bentuk budaya kaseise, nilai-nilai sosial kaseise, dan faktor yang menyebabkan budaya kaseise dalam penyelenggaraan Pernikahan Suku Muna (kakawi/kaga) masih tetap eksis di Desa Kombikuno Kecamatan Napano Kusambi. Sumber data dalam penelitian ini menggunakan data primer yaitu data melalui kegiatan observasi, dan wawancara guna menjawab permasalahan penelitian dan data sekunder yaitu data berupa catatan-catatan dan dokumentasi tentang keadaan geografis lokasi. Penelitian ini merupakan penelitian deskriptif kualitatif. Teknik pengumpulan data yang digunakan adalah wawancara, observasi dan dokumentasi. Untuk teknik penentuan informan menggunakan teknik purposive Sampling. Teknik analisis data yang digunakan yaitu analisis model interaktif menggunakan tiga tahapan yaitu reduksi data, penyajian data dan penarikan kesimpulan atau verifikasi. Hasil dalam penelitian ini menunjukkan bahwa budaya Kaseise dalam penyelenggaraan pernikahan suku Muna (Kakawi/kaga) di Desa Kombikuno Kecamatan Napano Kusambi mempunyai empat bentuk yaitu Kaseise dalam bentuk uang, Kaseise dalam bentuk bahan makanan, Kaseise dalam bentuk alatalat dapur dan Kaseise dalam bentuk non materi. Nilai-nilai sosial yang terkandung pada budaya Kaseise dalam penyelenggaraan Pernikahan suku Muna (kakawi/kaga) di Desa Kombikuno Kecamatan Napano Kusambi yaitu nilai religi/agama, nilai kebersamaan, dan nilai ekonomi. Adapun faktor yang menyebabkan budaya Kaseise dalam penyelenggaraan pernikahan suku Muna (Kakawi/kaga) masih tetap eksis di Desa Kombikuno Kecamatan Napano Kusambi karena dua faktor yaitu faktor pengembangan budaya dan faktor kewajiban sosial.
\end{abstract}

Kata Kunci: Kakawi/Kaga, Kaseise, Masyarakat Muna.

\section{PENDAHULUAN}

Kehidupan bersama manusia dalam wadah yang lazim disebut masyarakat, merupakan struktur dan proses yang perlu dipelajari dengan seksama. Disamping itu, sejak manusiamengenalkebudayaandanperadaban, masyarakatManusiasebagai proses pergaulan hidup telah menarik perhatian. Banyak pendekatan yang dapat digunakan dalam menelaahnya dan pendekatan model konseptual atau sematik (wawasan) system social budaya merupakan salah satu pilihan.

Indonesia merupakan masyarakat yang majemuk. Setiap daerah di Indonesia memiliki budaya tersendiri. Keanekaragaman budaya tersebut merupakan potensi sosial yang membentuk karakter dan citra budaya tersendiri pada masing-masing daerah. Budaya merupakan sesuatu yang telah lama dilakukan dan kini menjadi bagian dari kehidupan bermasyarakat, berawal dari suatu kebiasaan yang kemudian diteruskan dari generasi ke generasi selanjutnya. Kebudayaan adalah perulangan dari keseluruhan tindakan dan aktivitas manusia dan produk yang dihasilkan manusia 
yang telah memasyarakat secara sosial bukan sekedar dialihkan secara genetikal. Salah satu kebudayaan masyarakat Muna adalah Kaseise yang terdapat pada penyelenggaraan kakawilkaga (pernikahan).

Kaseise sangat berkaitan erat dengan sikap toleransi yang tinggi. Hal ini merupakan modal awal bagi individu untuk menjalankan kehidupan sosial. Individu adalah makhluk sosial, dan makhluk sosial tidak dapat hidup sendir. Jadi perlunya interaksi dan kerjasama yang baik dengan individu yang lain untuk memenuhi kebutuhan hidup. Disinilah makna Kaseise tersebut perlu diterapkan. Setelah menjalin hubungan dan kerjasama yang baik, menjunjung tinggi sikap toleransi, meningkatkan rasa simpati dan empati diri, pada masa yang akan datang seseorang tidak akan kesulitan untuk berpartisipasi dalam kegiatan masyarakat.

Budaya Kaseise memang sudah sedikit memudar di wilayah perkotaan, karena pada umumnya masyarakat perkotaan lebih bersifat individual dan juga tidak saling mengenal karena banyak masyarakat pendatang atau bukan penduduk asli Muna. Akan tetapi di Desa Kombikuno, Kecamatan NapanoKusambi masih sangat kental. La Awo selaku Kamokulano Liwn (Orang Tua Kampung) di Desa Kombikuno, Kecamatan Napano Kusambi mengatakan bahwa budaya Kaseise di Desa tersebut dari tahun ke tahun selalu meningkat. Masyarakat memiliki antusias yang cukup tinggi dalam hal tolong-menolong. Masyarakat disana memiliki rasa simpati dan empati yang tinggi, mereka taksungkan untuk saling membantu. Di Desa Kombikuno, Kecamatan Napano Kusambi rasa kekeluargaan dalam masyarakatnya masih sangat kental. Hal ini diperkuat oleh salah seorang masyarakat kota Kendari yang pernah melangsungkan pernikahan di Desa Kombikuno, LandiFinu mengatakan budaya tolong-menolong yaitu budaya Kaseise masi diterapkan pada Penyelenggaraan kakawi/kaga (pernikahan). Kakawi/kaga diselenggarakan dengan beberapa tahapan yaitu: Dofofeena (Melamar); apabila diterima dilanjutkan dengan prosesi Dofoampe Doi (melengkapi adat); dilanjutkan dengan Dehatoro Wakutu (Menentukan hari pernikahan); kemudian Gholeono Kakawi (hari pernikahan); dan yang terakhir adalah Kafosulino Katulu (kembali kerumah mempelai pria setelah empat malam menginap di rumah mempelai wanita).

Tolong-menolong sangat dibutuhkan oleh setiap individu, karena tidak ada invidu yang dapat bertahan hidup tanpa ada bantuan dari orang lain, inilah yang disebut sebagai makhluk sosial bantuan tersebut baik berupa tenaga, pemikiran maupun dalam bentuk uang, ketika budaya tolong-menolong ini sudah terinternalisasi dalam diri masing-masing individu maka akan terjalinlah kerjasama, dan ketika kerjasama selalu aktif dilakukan dalam masyarakat, maka dari sinilah solidaritas sosial terbentuk (Putra, 2018).

Tolong-menolong adalah suatu kegiatan kerjasama dalam masyarakat yang melibatkan banyak orang untuk menyelesaikan suatu pekerjaan guna mencapai hasil yang efektif serta efisen. Hal ini yang dinamakan gotong royong. Selain itu tolongmenolong juga dapat dilakukan dengan member sesuatu kepada orang lain yang membutuhkan baik berupa materi maupun non materi sehingga ada rasa 
kekeluargaan yang terbentuk diantara pelaku-pelakunya. Inilah yang membuat penulis tertarik untuk mengkaji permaslahan tentang "Eksistensi Budaya Kaseise (Tolong-Menolong) Dalam Penyelenggaraan Pernikahan Suku Muna". Studi di Desa Kombikuno Kecamatan Napano Kusambi Kabupaten Muna Barat.

\section{METODE PENELITIAN}

Jenis pendekatan yang digunakan dalam penelitian ini bersifat deskriptif kualitatif yakni pendekatan yang menjelaskan fenomena yang empiris yang sesuai dengan fakta di lapangan. Unit analisi yang digunakan dalam penelitian ini adalah : Unit analisis data primer yakni unit yang menganalisis data yang diperoleh dari hasil pengamatan dan wawancara langsung dengan nara sumber yang banyak mengetahui pelaksanaan budaya Kaseise; Unit analisis data sekunder yakni unit yang menganalisis data yang berupa catatan dari dokumen-dokumen yang terdapat di kantor Desa Kumbikuno, mengenai jumlah penduduk dan data yang relevan dengan penelitian

Teknik pengumpulan data dalam penelitian ini adalah :

1. Pengamatan (observasi), yaitu pengumpulan data dengan cara melakukan pengamatan terhadap objek penelitian adalah dengan melihat berbagai macam aktifitas masyarakat Desa Kubikuno, hal ini dilakukan saat tahap studi eksplorasi guna mencari informasi awal dalam penelitian ini.

2. Wawancara (interview), yaitu teknik yang digunakan untuk memperoleh informasi langsung dan lebih mendalam sehingga dapat memahami kebudayaan Kaseise pada masyarakat Desa Kumbikuno.

3. Dokumentasi yaitu mengambil data-data dari dokumen-dokumen serta literatur yang ada kaitannya dengan penelitian ini.

Proses analisis data yang diterapkan dimulai dengan menelaah seluruh data dari berbagai sumber, yaitu wawancara, observasi, dokumen pribadi, foto dan sebagainya. Dalam penelitian ini, peneliti menggunakan analisis data model Miles dan Huberman, dimana aktivitas dalam analisis data kualitatif dilakukan secara interaktif dan berlangsung secara terus menerus sampai tuntas, sehingga datanya sudah jenuh, aktifitas dalam analisis data Miles dan Huberman yaitu sebagai berikut. Reduksi Data (Data Reduction) Reduksi data diartikan sebagai proses pemilihan, pemusatan perhatian pada penyederhanaan, pengabstrakan, dan transformasi data "kasar" yang muncul dari catatan tertulis di lapangan dan memfokuskan pada hal-hal penting dari sejumlah data lapangan yang telah diperoleh dan mencari polanya. Reduksi data berlangsung terus-menerus selama penelitian berlangsung; Penyajian Data (Data Display) Setelah hasil dari seperangkat reduksi, maka data tersebut diorganisasikan kedalam bentuk tertentu sesuai kemauan data, data dibiarkan sebebas-bebasnya, sedalam-dalamnya, dan yang sesungguhnya. Untuk melihat gambaran seutuhnya atau bagian-bagian tertentu dari penelitian, maka data tersebut disajikan (data display) dalam berbagai macam bentuk. Penyajian data dilakukan dalam bentuk uraian singkat, hubungan antarkategori, bagan, dan teks yang bersifat naratif baik yang bersumber dari petikan wawancara, hasil observasi, maupun dari dokumen; 
Penarikan Kesimpulan (Conclusion Drawing/Verivication) Proses pengumpulan data bukan merupakan langkah terakhir dan akan berhenti disitu, melainkan kesimpulan tersebut masih bersifat tentatif, kabur, diragukan, dan akan berubah jika tidak ditemukan bukti-bukti yang kaut. Karena itu kesimpulan selalu dilakukan pendalaman data secara interaktif hingga ditemukan kesimpulan yang benar-benar kredibel, tingkat keteralihan yang tinggi, konsisten, dan ketika dilakukan konfirmasi menghasilkan informasi yang sama.

\section{PEMBAHASAN}

\section{Bentuk Budaya Kaseise dalam Penyelenggaraan Pernikahan Suku Muna}

Dalam masyarakat Muna perilaku tolong menolong ini dikenal dengan kebudayaan Kaseise, yang terdapat dalam penyelenggaraan Kakawi/kaga (pernikahan) suku Muna. Kakawi/kaga dilaksanakan dengan beberapa tahapan yaitu: Dofofeena (Melamar); apabila diterima dilanjutkan dengan prosesi Dofoampe Doi (melengkapi adat); dilanjutkan dengan Dehatoro Wakutu (Menentukan hari pernikahan); kemudian Gholeono Kakawi (hari pernikahan); dan yang terakhir adalah Kafosulino Katulu (kembali kerumah mempelai pria setelah empat malam menginap di rumah mempelai wanita). Selama prosesi-prosesi inilahmasyarakat melakukan tolong menolong baik kalangan laki-laki maupun kalangan perempuan yang tua maupun yang muda, mereka memberikan bantuan kepada saudara karib kerabatnya dengan berbagai macam bentuk, entah itu dalam bentuk materi maupun non materi. Kaseise pada masyarak Muna khususnya Desa Kombikuno terbagi menjadi empatbentuk yaitu: Kaseise dalam bentuk uang; kaseise dalam bentuk bahan makanan; kaseise dalam bentuk benda; dan kaseise dalam bentuk non materi.

\section{Kaseise dalam Bentuk Uang}

Kaseise dalam bentuk uang adalah pemberian bantuan beruapa sejumlah uang yang besarannya tidak menentu, kisarannya antara dua puluh ribu rupiah sampai dengan jutaan rupiah. Itu tergantug pada status ekonomi orang yang memberikan bantuan dan statuskekerabatanya dengan orang yang diberi bantuan. Masyarakat Desa Kombikuno di Kecamatan Napano Kusambi mempunyai budaya tentang tolong menolong (Kaseise) tersendiri yakni dari kalangan Pegawai Negri Sipil dan Pekerja Swasta yaitu memberi bantuan dalam bentuk uang. Hal ini sesuai dengan salah satu unsur kebudayaan yaitu sistem mata pencaharian dimana hal ini berhubungan dengan wujud kebudayaan yaitu uang sebagai benda hasil karya manusia. Uang tidak banyak memerlukan penjelasan karena merupakan kebudayaan fisik. Bentuknya berupa hasil dari aktivitas, perbuatan, dan karya dari semua manusia dalam masyarakat. Sifatnya paling kongkrit, dimana uang dapat dilihat, diraba, dan difoto.

Begitu banyak warga masyarakat yang datang ke rumah tersebut untuk membawa Takamani (bantuan) berupa uang baik dari kalangan laki-laki maupun kalangan perempuan. Setiap warga yang datang akan disambut oleh tuan rumah dan diberi minuman biasanya teh atau kopi dan gorengan seperti pisang goreng atau ubi 
goreng. Usai sedikit berbincang-bincang masyarakat yang datang akan menyerahkan bantuanya kepada tuan pesta, mereka akan menyeluarkan uang tunai yang diisi dalam amplop lalu menyerahkanya. Setelah peneliti melakukan observasi tepat pukul 12.00 seluruh ampot yang berisi uang tadi dibuka dan dihitung jumlah keseluruhannya. Itu adalah sebuah wujud kebudayaan yaitu suatu kompleks aktivitas kelakuan berpola dari masyarakat desa Kombikuno. Wujud ini disebut sistem sosial yang terdiri dari aktivitas-aktivitas manusia yang berinteraksi, berhubungan serta bergaul antara yang satu dengan yang lainnya dan selalu menurut pola-pola tertentu yang berdasarkan adat tata kelakuan. Sebagai rangkaian aktivitas manusia-manusia dalam masyarakat suatu sistem sosial ini bersifat kongkrit terjadi disekeliling kita sehari-hari, sehingga penulis melakukan observasi, memfoto, dan mendokumentasikanya.

\section{Kaseise dalam Bentuk Bahan Makanan.}

Kaseise dalam bentuk bahan makanan, Kaseise ini diberikan oleh para petani/nelayan dengan memberikan bahan pokok seperti minyak goreng, minyak tanah, beras, telur, ikan dan lain sebagainya. Dalam pengimplementasian kebudayaan Kaseise ini ada bentuk lain selain uang. Masyaraakat yang berprofesi sebagai petani atau nelayan memberi bantuan kepada masyarakat yang sedang mengadakan acara pernikahan dalam bentuk bahan makanan. Bahan makanan yang mereka berikanpun cukup beragam, disesuaikan dengan bahan makanan yang mereka tanam dan hewan ternak yang mereka kembangbiakkan dikebun biasanya adalah pisang, kelapa, ubi, telur, pepaya, kundur, labu, minyak goreng, ayam, beras, bumbu-bumbu dapur dan lain sebagainya. Sedangkan nelayan akan memberi bantuan berupa hasil tangkapanya yang dianggap layak dikonsumsi untuk sebuah hajatan, jenisnya seperti ikan Lajang, Ikan Bubara, Ikan tongkol dan lain sebagainya.

Masyarakat desa Kombikuno menggunakan salah satu unsur kebudayaan, dimana Sistem teknologi dan peralatan merupakan produk dari manusia sebagai homofaber. Bersumber dari pemikiran yang cerdas dan tangannya yang dapat memegang sesuatu dengan erat, manusia dapat menciptakan dan mempergunakan alat untuk mencukupi kebutuhannya. Sehingga Bagi kaum perempuan mereka datang membantu bukan dengan tangan kosong tetapi membawa keperluan dalam pelaksanaan kakawi tersebut seperti minyak goreng, ayam, pisang, terigu, telur dan lain sebagainya. Bagi laki-laki biasanya mereka akan datang dengan tangan kosong, paling tidak mereka akan membawa kapak, parang dan lain-lain untuk memotongmotong dan lain sebagainya. Hal ini disebabkan karena istri merekalah yang biasanya membawa kaise untuk mewakili keluarga mereka, terkecuali istrinya tidak datang barulah ia yang akan membawa kaseise mereka.

\section{Kaseise dalam Bentuk Alat-alat Dapur}

Kaseise dalam bentuk benda adalah bantuan berupa benda. Berbeda dengan dua bentuk kaseise yang diberikan sebelumnya, bantuan jenis ini biasanya berbau pinjaman seperti alat-alat masak, alat makan dan minum serta benda-benda dapur lainya yang menunjang keberlangsungan berbagai rangkayan acara pernikahan. 
Bantuan yang diberikan masyarakat tidak hanya terpaku pada barang habis sekali pakai seperti uang dan bahan makanan, masyarakat juga memberi bantuan berupa peralatan untuk kelancaran hajatan yang akan diadakan. Keadaan ekonomi yang tidak begitu mumpuni membuat masyarakat tidak mampu membeli peralatan dalam skala yang besar, hal inilah kemudian yang mendorong masyarakat untuk meminjam beberapa jenis barang kepada masyarakat yang lainnya saat mengadakan pesta. Pada masyarakat kota hal ini biasanya juga terjadi akan tetapi kegiatan seperti ini adalah salah satu cabang bisnis. Masyarakat yang mengadakan pesta akan menyewa barang-barang untuk diguanakan pada saat acara. Di desa khususnya desa Kumbikuno masyarakat meminjamkan barang-barang mereka secara Cuma-Cuma tanpa imbalan apapun, mereka melakukan itu semata-mata untuk menolong dan meringankan beban salah satu warga yang melangsungkan hajatan tersebut.

\section{Kaseise dalam Bentuk Non Materi}

Kaseise dalam bentuk non materi adalah bantuan berupa tenaga, pikiran dan lain sebagainya yang bukan berwujud materi. Di desa kombikuno kaseise inilah yang paling fenomenal apapun wujudnya dalam kehidupan sehari-hari. Kaseise biasa disebut gotong royong, saling bantu membentu untuk menyelesaikan pekerjaan akan membuat pekerjaan dilakukan secara efektif maupun efisien. Tidak hanya pada penyelenggaraan pernikahan, hal ini juga diterapkan pada pembangunan rumah, kerja bakti, pembangunan masjid, peringatan hari kamatian dan lain-lain.

Penulis menjumpai banyak sekali orang yang berkunjung dan membantu segala persiapan yang dilakukan guna kelancaran prosesi pernikaha. Kebayakan wanita yang datang membawa pisau dari rumah mereka masing-masing, yang lelaki membawa parang atau kampak, dan ada pula yang datang dengan tangan hampa tetapi tujuannya sama untuk membantu menyelesaikan pekerjaan ditempat tersebut. Saat itu tepatnya dua hari sebelum pernikahan dilangsungkan, para laki-laki saling gotong-royong untuk membuat sebuah bangsal didepan rumah mempelai mengingat rumahnya tidak terlalu luas jadi membuthkan ruang tambahan untuk berkumplnya masyarakat.

Sementara kaum adam mendirikan bangsal, para kaum hawa memasak makanan untuk dimakan pada hari itu. Mereka saling tolong-menolong dan saling membantu untuk meramu makanan, hal inilah yang membuat Kaseise didesa Kombikuno sangat kompleks karena secara bentuk sangat lengkap. Selain memasak para perempuan ini akan saling berkomunikasi serta mempererat silaturami mereka, biasanya mereka akan bercerita seputar pasangan yang akan melangsungkan pernikahan inilah yang kemudian menghasilkan produk baik berupa pujian maupun gunjingan masyarakat desa Kombikuno atas pernikahan tersebut.

Kaseise dalam bentun non materi ini adalah praktek dari wujud kebudayaan yaitu Sebagai suatu kompleks dari ide-ide, gagasan, nilai-nilai, norma-norma, peraturan, dan sebagainya. Hal ini adalah wujud ideal dari kebudayaan. Sifatnya abstrak, tidak dapat di foto atau diraba. Lokasinya ada didalam nalar, dengan kata lain ada dalam alam pikiran warga masyarakat dimana kebudayaan itu bersangkutan. 
Istilah yang tepat untuk mewujudkan bentuk ini adalah adat atau adat istiadat. Dimana semua it tergambar melalui aktifitas yang dilakukan masyarakat desa Kombikuno.

Dari semua uraian tentang bentuk kaseise di atas, kita bisa lihat bahwa kehidupan masyarakat Muna di Desa Kombikuno menggambarkan jati diri makhluk sosial yang selalu tolong menolong dalam masalah-masalah tertentu.Hal ini kita bisa lihat implementasi Kaseise pada kalangan laki-laki dan perempuan yang selalu berusaha untuk menolong saudara-saudaranya. Atas karakter yang demikian sehingga untuk menyelesaikan segala problema yang ada dalam kehidupan masyarakat, termasuk dalam proses penyelenggaraan acara pernikahan dibutuhkan sikap kerja sama yang dapat mempermudah dan memecahkan masalah secara efektif dan efisien.

Tolong menolong, sebagai sebuah kebudayaan dalam sistem kemasyarakatan, timbul dalam masyarakat sebagai akibat dari keterbatasan anggota masyarakat ataupun lingkungan dalam memenuhi kebutuhannya. Dalam perspektif struktural fungsional, keberadaan kebudayaan tolong menolong (Kaseise) dalam struktur sosial masyarakat karena kebudayaan ini dapat menjadi komponen dalam struktur yang mampu mengatur pemenuhan kebutuhan masyarakat dalam kondisi keterbatasan masyarakat seperti menyelenggarakan acara pernikahan, sekaligus menjadi daya pengikat dan daya gerak masyarakat.

\section{Nilai-Nilai Sosial yang Terkandung dalam Budaya Kaseise}

Nilai-nilai sosial budaya yang terkandung dalam budaya Kaseise (tolong menolong) tidak terlepas dari konsep budaya itu sendiri yaitu unsur-unsur kebudayaan yang kemudian tertuang menjadi beberapa unsur social budaya. Hal ini diperkuat oleh hasil wawancara dan observasi yang dilakukan penulis di desa Kombikuno kecamatan Napano Kusambi. Berdasarkan hasil wawancara dengan informan dalam pelaksanaan budaya Kaseise pada masyarakat Muna di Desa Kombikuno mengandung nilai-nilai sebagai berikut; nilai religius, nilai kebersamaan serta nilai ekonomi. Keempat nilai-nilai yang terkandung dalam budaya Kaseise tersebut akan di uraikan berikut ini.

\section{Nilai religi/agama}

Agama atau kepercayaan merupakan salah satu potensi dasar dalam membangun kehidupan yang harmonis dalam hal kebersamaan dan material spiritual yang dapat memperkuat kehidupan masyarakat. Tuntutan terhadap nilainilai religius terhadap kehidupan sehari-hari lebih pada kebutuhan rohaniah yang berdasarkan pada filosofis religius. Disisi lain kepercayaan terhadap masyarakat semakin menciptakan kondisi sosial budaya lebih pada aspek-aspek universal sehingga hubungan-hubungan masyarakat, individuLebih terikat atas dasarkeyakinan yang dimilikinya.

Nilai religius memiliki kedudukan yang sentral dalam kebudayaan Kaseise sehingga mempengaruhi eksistensinya dalam kehidupan masyarakat karna di samping mendapatkan balasan dari manusia dan juga tatkala pentingnya men- 
dapatkan pahala dari Allah SWT.Nilai agama dalam Kaseise tidak terlepas dari konsep nilai agama suatu masyarakat. Dalam kaitan ini, agama merupakan sistem yang terdiri dari konsep-konsep yang dipercaya dan menjadi keyakinan mutlak suatu umat, serta hubungan manusia dengan alam sekitar, manusia, dan alam gaib. Kehadiran agama Islam di Muna membawa pengaruh yang sangat besar dengan kehidupan masyarakat.Hal ini tercermin dari pola pikir, aturan-aturan, gagasan-gagasan, dan keyakinan yang berkembang dalam masyarakat

Begitu cerdiknya orang tua-orang tua terdahulu yang ada di Desa Kombikuno memanfaatkan ketaatan mereka terhadap kebudayaan sehingga mereka mengusahakan bagaimana caranya supaya warga masyarakat Muna di Desa Kombikuno bisa menyelesaikan sala satu kewajiban mereka sebagai seorang muslim. Mereka yang suka menolong orang lain dijanjikan akan mendapat penggantinya sesuai perbuatannya, baik didunia maupun di akhirat. Tentu saja dalam memberikan pertolongan kepada orang lain jangan berlebihan. Hal penting dalam melakukan perbuatan yang dianjurkan syara" ${ }^{\text {ee }}$ seperti menolong atau melonggarkan kesusahan orang lain, adalah tidak mengharapkan pamrih tertentu dari orang yang ditolong, melainkan ikhlas adalah semata-mata didasari rasa iman dan ingin mendapat RidhaNya.

Manusia diciptakan Allah SWT sebagai makhluk sosial yang mana manusia tidak bisa memenuhi kebutuhannya sendiri tanpa berinteraksi dengan manusia lain. Dalam kehidupan sehari-hari manusia pasti saling membutuhkan satu sama lainnya. Oleh sebab itu diwajibkan bagi mereka untuk saling tolong menolong antar sesama umat manusia, tidak jarang dalam memenuhi kehidupan pribadi, seseorang adakalanya tidak mampu memenuhinya sendiri, sehingga memerlukan orang lain. Manusia sebagai makhluk sosial, sangat membutuhkan orang lain untuk memenuhi kebutuhannya. Bahkan orang kaya sekalipun juga membutuhkan bantuan orang lain untuk memenuhi kebutuhannya. Sebagai seorang hamba diwajibkan bagi kita untuk saling tolong menolong antar sesama umat manusia karena seseorang adakalanya tidak mampu untuk memenuhinya sendiri, sehingga memerlukan orang lain. Jika seseorang menbantu meringankan atau melonggarkan kesusahan saudaranya berarti dia telah menolong dirinya sendiri dan orang yang gemar menolong orang lain, Allah SWT juga akan menolongnya dari kesusahan di dunia dan di akhirat. Seperti juga agama lain, Islam adalah kekuatan spiritual dan moral yang mempengaruhi, memotivasi, dan mewarnai tingkah laku individu.

Menguraikan Islam yang tumbuh dikelompok masyarakat tertenta adalah menelusuri karakteristik Islam yang terbentuk dalam budaya atau tradisi yang populer di tengah masyarakat. Dengan asumsi bahwa, suatu budaya atau unsure tradisi bersifat Islami ketika pelakunya bermaksud atau mengaku bahwa tingkah lakunya sesuai dengan jiwa Islam. Dalam skala yang berbeda, dan dengan pengaruh yang lebih mendalam, akomodasi, dan akulturasi juga terwujud dalam bentuk sikap, gagasan, ide, adat, dan perilaku tertentu yang menjadi pedoman masyarakat setempat. Sebagai wujud internal dari nilai religi budaya Kaseise pada masyarakat 
Desa Kombikuno dapat di lihat pada saat pemberian uang dan bahan makanan, benda mereka berjabat tangan dan saling mendoakan.

Di samping itu wujud eksternal dari nilai religi budaya Kaseise dapat di lihat terwujudnya suasana keakraban keluarga yang mengimplementasikan Kaseise dengan warga sekitarnya maupun dari keluarga yang jauh yang sengaja datang memberikan sumbangan sehingga dengan momentum ini sekat-sekat konflik yang mungkin ada selama ini baik dalam tataran keluarga maupun dengan warga tetangganya akan terjalin kembali suasana keakraban di antara mereka. Dimana seluruh penjelasan diatas berkaitan dengan unsure kebudayaan yaitu Sistem religi dan upacara keagamaan yang Merupakan produk dari manusia sebagai homoreligius. Manusia memiliki kecerdasan pikiran dan perasaan leluhur, tanggap bahwa diatas kekuatan dirinya terdapat kekuatan lain yang Maha Besar. Oleh karena itu, manusia takut dan lahirlah kepercayaan yang sekarang menjadi agama

\section{Nilai Kebersamaan}

Masyarakat Desa Kumbikuno memiliki kesadaran penuh bahwa dia tidak dapat hidup sendiri dan tanpa bantuan orang lain. Secara psikologis setiap insan membutuhkan komunikasi dengan orang lain baik baik dengan sesama anggota keluarga (istri, kakak, adik, anak, dan orang tua) dengan tetangga, dengan masyarakat dalam komunitas bernegara. Rasa ini terus diwarisi secara berkesinambungan oleh masyarakat Desa Kumbikuno sebagai bentuk rasa solidaritas termasuk semangat pelestarian jiwa tolong-menolong dalam masyarakat. Secara nasional, filosofi pancasila terkandung nilai-nilai luhur semangat tolong-menolong dan gotong royong yaitu sikap dan perilaku bekerja sama untuk mencapai tujuan bersama. Hidup saling melengkapi antara individu dengan individu, individu dengan kelompok menyatu dalam tatanan dalam kehidupan kebangsaan dan bernegara karena tolong menolong merupakan keinginan spontan yang mendorong perasaan saling membutuhkan yang ada dalam jiwa masyarakar Desa Kumbikuno kecamatan Napano Kusambi.

Nilai kebersamaan itu muncul pada setiap anggota masyarakat yang ikut serta dalam budaya Kaseise pada masyarakat Desa Kumbikuno, rasa persaudaraan dan kebersamaan sesama warga semakin dekat dan erat. Hal ini dapat dinyatakan bahwa hubungan sosial antara masyarakat terjalin dengan baik dan harmonis. Peneliti melihat dengan adanya tolong menolong tersebut membuat hubungan antar sesama anggota masyarakat semakin bertambah akrab dan menimbulkan jalinan atau persaudaraan yang kuat. Bahkan dari kegiatan tersebut bisa memunculkan perasaan rela berkorban, entah dalam bentuk waktu, pikiran dan tenaga dengan tujuan untuk memenuhi kepentingan bersama.Selain itu keinginan ini bisa di jadikan sebagai media untuk saling memberi bantuan terutama bagi anggota masyarakat yang sedang membutuhkan bantuan atau pertolongan.

Tolong-menolong mencerminkan kebersamaan yang tumbuh dalam lingkungan masyarakat. Dengan tolong menolong masyarakat mau bekerja sama untuk membantu orang lain atau untuk membangun fasilitas yang bisa di manfaatkan bersama. Dengan anggapan bahwa manusia merupakan makhluk sosial 
yang tidak dapat hidup sendiri melainkan adanya keterlibatan manusia lain dalam berbagai aspek kehidupan. Tolong menolong yang ada dalam suatu masyarakat membentuk mentalitas bangsa menjadi lebih berkarakter dan melahirkan banyak nilai-nilai luhur yang bermanfaat bagi kehidupan. Begitu pula dengan budaya Kaseise yang ada pada masyarakat Desa Kombikuno, mencerminkan asas kebersamaan sehingga membentuk rasa persaudaraan yang jauh lebih dekat.

Persepsi masyarakatmengenai pentingnya hidup rukun antara sesama maupun dengan masyarakat yang lain dalam sebuah lingkungan tertentu perlu dijaga dan dijadikan sebagai suatu modal penting untuk dipertahankan. Rasa kebersamaan ini muncul karena adanya sikap sosial dari masing-masing individu untuk meringankan beban yang sedang dipikul. Masyarakat desa Kombikno menjalankan salah satu unsur kebudayaan yaitu Sistem organisasi kemasyarakatan yang Merupakan produk dari manusia sebagai homosocius melalui akal manusia membentuk kekuatan dengan cara menyusun organisasi kemasyarakatan yang merupakan tempat bekerja sama untuk mencapai tujuan bersama, yaitu menciptakan kesejahteraan hidupnya.

Kebersamaan masyarakat Desa Kombikuno yang terjalin dalam tolong menolong sekaligus melahirkan persatuan antar anggota masyarakat. Dengan persatuan yang ada, masyarakat menjadi lebih kuat dan mampu menghadapi berbagai permasalahan yang muncul. Tolong-menolong dapat memupuk persatuan dan kesatuan antar manusia. Pentingnya hidup rukun dan bersatu antar sesama masyarakat sangat penting pada suatu daerah atau wilayah tertentu sehingga dapat terhindar dari kemungkinan terjadinya pertikaian dan menjadikan masyarakat lebih bermartabat. Dalam menjaga keutuhan dan persatuan dalam masyarakat maka diperlukan sikap saling menghormati dan saling menghargai, sehingga gesekangesekan yang dapat menimbulkan pertikaian dapat dihindari.Masyarakat juga dituntut untuk menjaga hak dan kewajiban mereka antara satu dengan yang lainnya.

\section{Nilai Ekonomi}

Pada dasarnya kebudayaan diciptakan oleh Manusia karna menurut mereka dengan adanya kebudayaan tersebut dapat memberikan asas manfaat bagi masyarakat secara umum. Kebudayaan Kaseise inilah yang mereka bentuk dan mempunyai banyak manfaat dan untuk kehidupan masyarakat terkhusus dalam kondisi ekonomi atau kondisi keuangan. Kaseise berperan penting untuk meringankan beban ekonomi keluarga yang mengadakan pesta dalam acara pelaksanaan pernikahan (Kakawi/kaga). jadi, nilai ekonomi yang terdapat dalam budaya Kaseise nampak dalam bentuk pelaksanaannya yaitu pemberian bantuan bantuan berupa uang, bahan makanan seperti minyak goreng, telur, gula, terigu, pisang, minyak tanah, beras, ayam, dan lain sebagainya; benda yakni piring, sendok, gelas, tempat menyajikan nasi, mangkok, panic, wajan, sutil dan masih banyak lagi serta pemberian bantuan berupa pikiran dan tenaga sekaligus waktu demi menyukseskan sebuah acara pernikahan. 
Dengan adanya kebudayaan tolong meolong (Kaseise) dalam pelaksanaan acara pernikahan (kakawi/kaga) secara ekonomi dapat terbantu bagi keluarga yang mengadakan pesta, dalam hal ini adalah acara pelaksanaan pernikahan.

1. Dengan adanya kebudayaan tolong menolong (Kaseise) yang terdapat dalam kakawini dapat membantu meringankan beban keluarga yang mengadakan acara pernikahan.

2. Ketika penyelenggaraan acara pernikahan (Kakawi/kaga) diadakan seacar besarbesaran maka keluarga-keluaga akan berkumpul dan bisa menjalin silaturahim kembali, karna dalam acara tersebut menyebarkan undangan untuk keluarga.

3. Selain silaturahim bersama keluarga, dengan adanya acara tersebut dapat memberikan manfaat silaturahim pada warga masyarakat dalam desa dan warga masyarakat desa-desa tetangga.

\section{Faktor Penyebab Eksistensi Budaya Kaseise dalam Penyelenggaraan Pernikahan Suku Muna}

\section{Faktor Pengembangan Budaya}

Pulau Muna memiliki berbagai macam budaya yang sudah berakar dan di yakini telah ada pada masyarakat seiring dengan keberadaan mereka di pulau Muna, namun dengan perkembangan dan akibat modernisasi hasil-hasil Kebudayaan tersebut mulai mengalami perubahan, bahkan cenderung di tinggalkan. Padahal budaya tersebut memiliki nilai-nilai yang sangat bermanfaat bagi kelangsungan hidup masyarakatnya. Salah satu budaya tradisional yang masih sering di laksanakan adalah budaya Kaseise yang lahir sebagai akibat pembaruan antara budaya lokal dan budaya Islam. Budaya Kaseise (Tolong menolong) merupakan tradisi pemberian bantuan terhadap masyarakat lain dengan yang berupa materil dengan tujuan meringankan beban keluarga yang menyelenggarakan pernikahan, yang kerap dilaksanakan dari dulu sampai sekarang di wilayah bagian barat Muna yakni di Kecamatan Napano Kusambi.

Manusia pada dasarya sebagai makhluk yang ingin bekerja sama dalam upaya memenuhi kepentingan sosial dan kepentingan individu atau personal memiliki sistem kerja sama, gotong royong, dan tolong-menolong artinya bahwa masyarakat ikut berkontribusi dalam sebuah acara hajatan dan pekerjaan dilandasi atas dasar keikhlasan dengan semangat kebersamaan tanpa meminta suatu imbalan baik berupa materil maupun bentuk jasa. Sama halnya dengan Kaseise yang merupakan sistem tolong menolong yang berlaku dalam acara penyelenggaraan pernikahan masyarakat Muna terkhusus di Desa Kumbikuno Kecamatan Napano Kusambi. Secara nyata, tradisi Kaseise telah melembaga dan mengakar kuat. Ini diwujudkan dalam setiap acara pelaksanaan acara pernikahan. Khususnya di pedesaan Muna, semakin tahun semakin berkembang.

Kaseise patut diberikan apresiasi dan patut di kembangkan dan juga patut di pertahankan oleh warga masyarakat karena kebudayaan atau tradisi ini mempunyi nilai positif. Artinya bahwa tradisi ini memiliki posisi yang sentral dalam membentuk solidaritas sosial masyarakat. Pelaksanaan Kaseise terekspresikan dalam penyeleng- 
garaan acara pernikahan Kakawi/kaga yang dilaksanakan dengan beberapa tahapan yaitu: Dofofeena (Melamar); apabila diterima dilanjutkan dengan prosesi Dofoampe Doi (melengkapi adat); dilanjutkan dengan Dehatoro Wakutu (Menentukan hari pernikahan);kemudian Gholeono Kakawi (hari pernikahan); dan yang terakhir adalah Kafosulino Katulu (kembali kerumah mempelai pria setelah empat malam menginap di rumah mempelai wanita). Segala tahapan yang di wujudkan dalam pertukaran jasa atau azas timbal balik. Secara umum aktifitas tolong menolong memiliki tema sentral mutual help antara anggota masyarakat, dimana masing-masing pihak yang terlibat saling memberikan kontribusi.

\section{Faktor Kewajiban Sosial}

Masyarakat sebagai makhluk sosial selalu membutuhkan bantuan dari orang lain. Dimana seorang individu tidak akan bisa bertahan hidup dalam memenuhi kebutuhannya sendiri jika orang lain tidak turut serta dalam aktifitasnya. Individu yang dibantu di dalam hatinya pasti memiliki perasaan utang budi dari sinilah dia berusaha untuk membalas budi kebaikan orang yang membantunya. Prinsip seperti ini disebut sebagai prinsip timbal balik (principleof resiprocity) begitulah kehidupan masyarakat Desa Kombikuno selama ini. Dalam prosesnya, tolong-menolong menjalankan prinsip timbal balik (refisiprocity) dan merupakan sebuah pertukaran sosial. Pertolongan yang diberikan oleh seseorang menimbulkan kewajiban kepada pihak yang di tolong untuk membalasnya secara seimbang, dan pada diri pihak pemberi pun muncul harapan akan adanya balasan pemberiannya meskipun tidak sesuai yang diberikan.

Masyarakat melakukan tolong menolong dalam Kaseise ini memiliki prinsip timbal balik, namun jika tidak ada timbal balik dari pihak yang di tolong maka dia akan dikenakan sanksi sosial oleh masyarakat setempat. Dari pernyataan ini membuat warga yang hidup di dalam lingkup Desa Kombikuno Kecamatan Napano Kusambi mau tidak mau mereka harus melaksanakan Kaseise dikarenaka hidup ini akan membutuhkan pertolongan orang lain.

Kebudayaan tolong menolong (Kaseise) pada hakikatnya dibentuk ditengahtengah Desa Kombikuno dengan prinsip untuk mengurangi beban ekonomi keluarga yang mengadakan hajatan pernikahan (kakawi/kaga). Karena pada dasarnya manusia sebagai makhluk yang berpikir, mempunyai kreatifitas dalam menciptakan suatu kebudayaan dan itu akan bermanfaat pada keberlangsungan hidup mereka sendiri. Dimana kebudayaan Kaseise ini memiliki prinsip resiprositas yang artinya bahwa semua masyarakat yang ada dalam daerah tersebut akan merasakan semuanya. Dan kebudayaan ini telah melembaga dalam masyarakat yang sebagai sebuah sistem sosial.

Kaseise mempunyai tujuan untuk meringankan beban ekonomi keluarga yang menyelenggarakan pesta. Sistem sosial menangani fungsi integrasi dengan mengendalikan bagian-bagian komponennya: dalam kebudayaan Kaseise mempunyai prinsip resiprositas atau timbal balik, karna hal ini secara tidak langsung memotifasi masyarakat untuk mengimplementasikan kebudayaan tersebut. Sedangkan terakhir 
adalah sistem budaya melaksanakan fungsi latensi dengan menyediakan normanorma dan nilai-nilai bagi para aktor yang memotivasi mereka untuk bertindak: dengan prinsip resiprosiatas maka masyarakat mempunyai kewajiban untuk melakukan timbal balik jika tidak individu tersebut mendapatkan sanksi sosial. Sanksi sosial tersebut berupa pengisolasian dalam suatu lingkungan tersebut.

\section{PENUTUP}

\section{Kesimpulan}

Berdasarkan hasil penelitian dan pembahasan yang telah di jabarkan dapat disimpulkan sebagai berikut

1. Bentuk budaya Kaseise dalam penyelenggaraan pernikahan suku Muna (Kakawi/kaga) di Desa Kombikuno Kecamatan Napano Kusambi terbagi atas empat bentuk yaitu:

a. Kaseise dalam bentuk uang yakni pemberian bantuan beruapa sejumlah uang yang besarannya tidak menentu, kisarannya antara dua puluh ribu rupiah sampai dengan jutaan rupiah. Itu tergantug pada status ekonomi orang yang memberikan bantuan dan statuskekerabatanya dengan orang yang diberi bantuan. Dan biasanya bantuan berupa ini diberikan oleh para Pegawai Negri Sipil atau pekerja swasta;

b. Kaseise dalam bentuk bahan makanan, Kaseise ini diberikan oleh para petani/nelayan dengan memberikan bahan pokok seperti minyak goreng, minyak tanah, beras, telur, ikan dan lain sebagainya;

c. Kaseise dalam bentuk alat-alat dapur adalah bantuan berupa alat-alat dapur. Berbeda dengan dua bentuk kaseise yang diberikan sebelumnya, bantuan jenis ini biasanya berbau pinjaman seperti alat-alat masak, alat makan dan minum serta benda-benda dapur lainya yang menunjang keberlangsungan berbagai rangkayan acara pernikahan.

d. Kaseise dalam bentuk non materi adalah bantuan berupa tenaga, pikiran dan lain sebagainya yang bukan berwujud materi. Di desa kumbikuno kaseise inilah yang paling fenomenal apapun wujudnya dalam kehidupan sehari-hari.

2. Nilai-nilai sosial yang terkandung pada budaya Kaseise dalam penyelenggaraan pernikahan suku Muna (Kakawi/kaga) di Desa Kombikuno Kecamatan Napano Kusambi budaya Kaseise (Tolong menolong)

a. Nilai religi yang ada dalam budaya Kaseise (tolong menolong) mempunyai nilai ibadah yang tentunya akan bermanfaat di dunia dan di akhirat. Karna kebaikan yang dilakukan akan kembali pada diri sendiri.

b. Nilai kebersamaan yang ada dalam budaya Kaseise (tolong menolong) sangat bermanfaat bagi kehidupan sosial pada suatu daerah maupun wilayah tertentu.

c. Nilai ekonomi sangat bermanfaat dalam meringankan beban ekonomi dalam pelaksanaan acara pernikahan (Kakawi/kaga) 
3. Faktor yang menyebabkan Budaya Kaseise dalam penyelenggaraan pernikahan suku Muna (Kakawi/kaga) masih tetap eksis di Desa Kombikuno Kecamatan Napano Kusambi.

a. Faktor Pengembangan Budaya yang menyebabkan Kaseise masi tetap eksis sampai sekarang karena masyarakat Desa identik dengan keloyalan terhadap kebudayaan. Dan budaya ini terus menerus disosialisasikan sehingga tidak punah.

b. Faktor kewajiban sosial, dimana manusia tidak dapat bertahan hidup tanpa bantuan orang lain, akhirnya dia akan membantu saudara-saudaranya karna prinsip timbal balik (resiprocity). Yang mendorong individu untuk berprinsip resiprositas karena adanya sanksi sosial di wilayah tersebut.

\section{Saran}

Dari kesimpulan hasil penelitian tersebut penulis mengajukan beberapa saran sebagai berikut:

1. Diharapkan kepada seluruh masyarakat Kabupaten Muna umumnya dan masyarakat desa Kombikuno khususnya untuk terus mempertahankan dan menerapkan budaya Kaseise dalam aktifitas social maupun kearifan lokal lainnya sebagai kekayaan budaya dan identitas masyarakat Muna.

2. Bagi mahasiswa yang akan melakukan penelitian selanjutnya hendaknya lebih mengembangkan pembahasan yang diteliti dan mencari referensi lebih lengkap untuk memudahkan dalam mendapatkan data yang lebih baik dan akurat serta dapat menjadi rujukan dalam penelitian yang serupa dengan penelitian ini.

3. Bagi pemerintah daerah seharusnya memperhatikan kebudayaan-kebudayaan lokal yang ada di pedesaan termasuk kebudayaan Kaseise yang ada di kabupaten Muna, karena kebudayaan ini dapat dijadikan sebagai sebuah kearifan local.

\section{DAFTAR PUSTAKA}

Ahmadi. 2007. Psikologi Sosial. Jakarta: Rineka Cipta.

Ahmdi dan Prasetya.2005. Strategi Belajar Mengajar (SBM). Bandung: Pustaka Setia.

Burhan, Bungin. 2007. Penelitian Kualitatif. Jakarta: Prenada Media Group.

Gunawan, Samuel. 1999. Antropologi Budaya. Jilid 1: Suatu Perspektif Kontemporer. Jakarta: Erlangga.

Harwantiyoko. 1997. MKDU Ilmu Sosial Dasar. Jakarta: Gunadarma.

Horton, P.B. dan Hunt, C.L. 2006. Sosiologi. Terjemahan Drs. Aminuddin Ram, M. Ed. Jakatra: Erlangga.

Johnson, Paul Doyle. 1986. Teori Sosiologi Klasik dan Modern. Jakarta: Gramedia Pustaka Utama.

Kalangie, Nico S. 1994. Kebudayaan dan Kesehatan: Pengembangan Pelayanan Kesebatan Primer Melalui Pendekatan Sosiobudaya. Jakarta: PT Kesaint Blanc Indah Corp.

Martono, Nanang. 2012. Sosiologi Perubahan Sosial: Perspektif Klasik, Modern, Posmodern, dan Poskolonial. Jakarta: PT. Raja Grafindo Persada. 
Moleong J. Lexy. 2007. Metodologi Penelitian Kualitatif. Bandung: Remaja Rosda Karya.

Polama, Margaret, M. 2000. Sosiologi Kontemporer. Jakarta: Raja Grafindo Persada. 2012. Teori Sosiologi. Yogyakarta: Pustaka Pelajar

Taylor. E. Ishelly.2013 Psikologi Sosial Edisi Kedua Belas. Jakarta: Kencana.

Upe, Ambo dan Juhaepa. 2011. Eksistensi Nilai Tolong-Menolong Pada Masyarakat Bugis, Kajian atas Assitulung-Tulungeng pada Prosesi Pernikahan. Jurnal Sumber Daya Insani. Universitas Muhamadiyah Kendari. Edisi 2011 No. 20.

Upe, Ambo. 2016. Metode Penelitian Sosial: Filosofi dan Desain Praktis. Kendari: Literacy Institute. 